\title{
Papers
}

\section{Mortality and smoking in Hong Kong: case-control study of all adult deaths in 1998 Topic: 157;49;163;144}

\author{
T H Lam, S Y Ho, A J Hedley, K H Mak, R Peto
}

\begin{abstract}
Objective To assess the mortality currently associated with smoking in Hong Kong, and, since cigarette consumption reached its peak 20 years earlier in Hong Kong than in mainland China, to predict mortality in China 20 years hence.

Design Case-control study. Past smoking habits of all Chinese adults in Hong Kong who died in 1998 (cases) were sought from those registering the death. Setting All the death registries in Hong Kong. Participants 27507 dead cases (81\% of all registered deaths) and 13054 live controls aged $\geqslant 35$ years. Main outcome measures Mortality from all causes and from specific causes.

Results In men aged 35-69 the adjusted risk ratios (and 95\% confidence intervals) comparing smokers with non-smokers were 1.92 (1.70 to 2.16) for all deaths, 2.22 (1.94 to 2.55) for neoplastic deaths, 2.60 (2.10 to 3.21) for respiratory deaths (including tuberculosis, risk ratio 2.54 ), and 1.68 (1.43 to 1.97 ) for vascular deaths (each $\mathrm{P}<0.0001)$. In women aged 35-69 the corresponding risk ratios were 1.62 (1.40 to 1.88 ) for all deaths, 1.60 (1.33 to 1.93) for neoplastic deaths, 3.13 (2.21 to 4.44) for respiratory deaths, and 1.55 (1.20 to 1.99 ) for vascular deaths (each $\mathrm{P}<0.001)$. If these associations with smoking are largely or wholly causal then, among all registered deaths at ages 35-69 in 1998, tobacco caused about $33 \%(2534 / 7588)$ of all male deaths and $5 \%$ (169/3341) of all female deaths (hence $25 \%$ of all deaths at these ages). At older ages tobacco seemed to be the cause of 15\% (3017/20 420) of all deaths. Conclusions Among middle aged men the proportion of deaths caused by smoking is more than twice as big in Hong Kong now (33\%) as in mainland China 10 years earlier. This supports predictions of a large increase in tobacco attributable mortality in China as a whole.
\end{abstract}

\section{Introduction}

Tobacco related mortality needs to be assessed separately in many different populations, as it may differ substantially from one population to another in ways that are difficult to predict. Some of these differences involve poorly understood cofactors for neoplastic, respiratory, and vascular disease, and some involve differences in the type and amount of tobacco smoked during previous decades (because the full hazards of persistent smoking may take about half a century to emerge). In the United Kingdom and United States, for example, a large increase in cigarette consumption between 1910 and 1950 resulted in a large increase in tobacco related deaths between 1950 and $1990{ }^{1}$

China, with $20 \%$ of the world's population, now smokes $30 \%$ of the world's cigarettes, ${ }^{1}$ and direct evidence is needed of the eventual effects of this on Chinese mortality. However, the main increase in cigarette consumption took place 40 years later in China than in the United States, so it is too early for the full hazards yet to be seen, and we cannot necessarily assume that the disease specific hazards in China will be similar to those documented in Western countries. Large case-control studies were therefore conducted in mainland China that assessed the hazard 10 years ago, ${ }^{2}$ and large prospective studies have been set up that will eventually monitor the evolution of the Chinese epidemic of tobacco attributable mortality, ${ }^{3}$ but it will be some decades before these prospective study results mature.

In the largely $(95 \%)$ Chinese population of Hong Kong, however, the prevalence of cigarette smoking reached its peak about 20 years earlier than in mainland China (but about 20 years later than in the United States), ${ }^{45}$ and the present case-control study assesses the mortality currently associated with smoking among them.

\section{Subjects and methods}

We undertook a large case-control study in which the cases were all ethnic Chinese people aged 35 or over whose deaths were registered in Hong Kong in about 1998 (mid-December 1997 to mid-January 1999). For each such death, information was sought from the registry about the medical cause of death and from the person reporting the death about the dead person's smoking habits 10 years earlier-that is, before there was much chance of the habits being changed by the disease that eventually caused death.

In Hong Kong death registration at one of four death registries is required by law and is usually done by one of the more educated relatives of the dead person. Chinese informants registering an adult death were given a standardised questionnaire about the dead person while waiting in the registry for the death

\author{
Department of \\ Community \\ Medicine, \\ University of Hong \\ Kong, Patrick \\ Manson Building \\ South Wing, \\ 7 Sassoon Road, \\ Hong Kong \\ T H Lam \\ chair professor in \\ community medicine \\ S Y Ho \\ postdoctoral fellow \\ A J Hedley \\ chair professor in \\ community medicine \\ Department of \\ Health, \\ Government of the \\ Hong Kong Special \\ Administrative \\ Region \\ K H Mak \\ consultant in \\ community medicine \\ CTSU, University of \\ Oxford, Oxford \\ OX2 6HE \\ R Peto \\ co-director \\ Correspondence to: \\ T H Lam \\ commed@hkucc. \\ hku.hk
}

BMJ 2001;323:1-6 
certificate and were invited by trained interviewers to complete it or to let the interviewer complete it with them, recording smoking, drinking, employment, and housing type (each as they were " 10 years ago, in about 1988") and age, sex, birthplace, and educational attainment. The questionnaire (available from THL on request) was about lifestyle in general, and no indication was given that smoking was of particular interest.

The questionnaire had two sections asking the same questions, one for the dead person (case) and one for a living person-either the dead person's spouse or, if there was no surviving spouse, a person preferably aged at least 60 with whose habits 10 years ago the informant was most familiar (which generally yielded a relative of the dead person). We used the living person as a control, but only if that person was not the informant. Hence, for both cases and controls, information was obtained by proxy from the same informant and was related to habits in 1988 . When the informant was the spouse, which was common, no control was obtained: hence, there are only half as many controls as cases. Indeed, as our methods tended to select female controls (since wives tend to survive husbands) there were only a quarter as many male controls as male cases (although for each particular cause of death there were more male controls than male cases). For comparability with other studies, ${ }^{1-3}$ our mortality analyses are restricted to people aged 35 or above.

Interviewing was conducted from mid-December 1997 to mid-January 1999 and yielded complete infor-

Table 1 Demographic characteristics (\%) of cases and controls

\begin{tabular}{|c|c|c|c|c|}
\hline & $\begin{array}{l}\text { Male cases } \\
(\mathrm{n}=15296)\end{array}$ & $\begin{array}{c}\text { Male } \\
\text { controls } \\
(\mathrm{n}=3918)\end{array}$ & $\begin{array}{c}\text { Female cases } \\
(\mathrm{n}=12 \text { 211) }\end{array}$ & $\begin{array}{l}\text { Female controls } \\
\quad(n=9136)\end{array}$ \\
\hline \multicolumn{5}{|l|}{ Age (years): } \\
\hline $35-44$ & 4 & 1 & 3 & 2 \\
\hline $45-54$ & 8 & 4 & 5 & 10 \\
\hline $55-64$ & 15 & 17 & 8 & 23 \\
\hline $65-69$ & 14 & 16 & 8 & 19 \\
\hline $70-74$ & 16 & 22 & 14 & 20 \\
\hline $75-79$ & 16 & 16 & 16 & 13 \\
\hline $80-84$ & 14 & 15 & 18 & 9 \\
\hline$\geqslant 85$ & 13 & 9 & 28 & 4 \\
\hline \multicolumn{5}{|l|}{ Birthplace: } \\
\hline Hong Kong & 17 & 13 & 16 & 15 \\
\hline Guangdong & 71 & 75 & 72 & 74 \\
\hline Elsewhere & 12 & 12 & 12 & 11 \\
\hline \multicolumn{5}{|l|}{ Education: } \\
\hline No formal & 26 & 24 & 61 & 50 \\
\hline Primary & 47 & 49 & 27 & 36 \\
\hline Secondary & 22 & 22 & 10 & 12 \\
\hline Tertiary and higher & 5 & 4 & 2 & 2 \\
\hline \multicolumn{5}{|l|}{ Type of housing: } \\
\hline Hut or shared & 11 & 5 & 9 & 6 \\
\hline Public housing & 47 & 50 & 44 & 48 \\
\hline Self owned & 36 & 41 & 39 & 41 \\
\hline Quarter or other & 6 & 4 & 8 & 5 \\
\hline \multicolumn{5}{|l|}{ Job: } \\
\hline Full time & 41 & 42 & 11 & 19 \\
\hline Retired & 55 & 55 & 33 & 24 \\
\hline House work & 0 & 0 & 50 & 49 \\
\hline Part time, jobless, or student & 4 & 3 & 7 & 8 \\
\hline \multicolumn{5}{|l|}{ Smoking status: } \\
\hline Ever smoked & 69 & 60 & 21 & 13 \\
\hline Never smoked & 31 & 40 & 79 & 87 \\
\hline
\end{tabular}

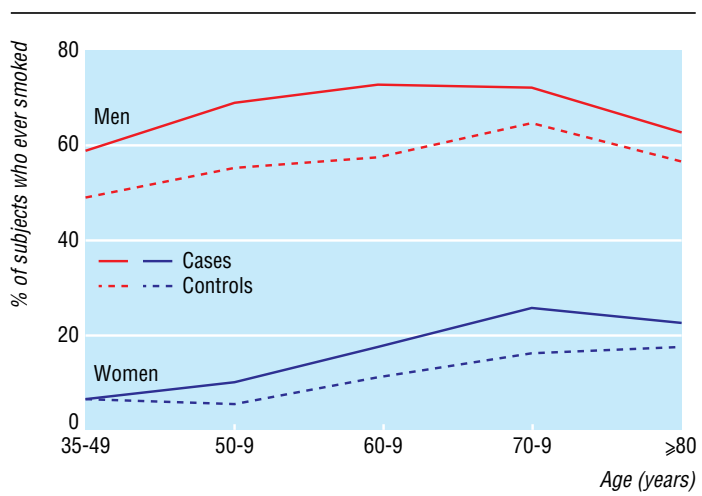

Reported smoking habits of 27000 dead "cases" and 13000 live controls in Hong Kong in 1998 stratified by age and sex

mation on 27507 cases aged 35 or over (mean 2116 per month, which is $81 \%$ of the monthly number of death registrations at these ages during 1998 in the whole of Hong Kong) and on 13054 controls. Of the deaths that were not included, a third were because of the informant's refusal or inability to provide complete information and the rest were either because the informant was not Chinese or, more commonly, because when one interview was in progress another informant might be missed. As a check on reliability, repeat interviews were conducted by telephone on a random sample of 235 cases and 212 controls: the agreement over whether people had ever smoked was $91.9 \%$ for cases and $92.0 \%$ for controls.

Causes of death were routinely coded according to the World Health Organisation's ninth international classification of diseases (ICD-9) by the governmental Department of Health. The main disease groupings used in the present analyses are those previously adopted by a large study ${ }^{2}$ in mainland China, but with some extra subcategories added (colorectal cancer and injury and poisoning).

\section{Statistical analysis}

Unmatched logistic regression was used to estimate the risk ratio for smokers versus non-smokers adjusted for age (five year age groups) and education (four categories). If a proportion $p$ of the study deaths involved smokers then the fraction attributed to smoking (calculated separately for men and women aged 35-69 and $\geqslant 70)$ is $p \times(1-1 /($ risk ratio $))$, and was multiplied by the corresponding number of deaths registered in all Hong Kong to get attributed numbers.

\section{Results}

The cases and controls had similar birthplaces, education, type of housing, and jobs (see table 1 ). The mean (SD) age of cases and controls was 70.7 (12.7) and 71.5 (10.3) for men but was 76.3 (13.2) and 67.3 (10.5), respectively, for women. These differences in age are controlled for automatically in the analyses. The proportion of people who had ever smoked was greater in cases than in controls both for men and for women, indicating higher death rates among smokers than among non-smokers at all ages (see figure: the apparent irregularity among women aged 35-49 is based on small numbers, and the upper $95 \%$ confidence limit for the corresponding risk ratio is 1.5). 
Table 2 Numbers of subjects who ever smoked or never smoked and adjusted risk ratiost for smoking and mortality from neoplastic, respiratory, vascular, and other causes among 27507 dead "cases" and 13054 live controls in Hong Kong, 1998

\begin{tabular}{|c|c|c|c|c|}
\hline \multirow[b]{2}{*}{ Cause of death } & \multicolumn{2}{|c|}{ Age $35-69$ years } & \multicolumn{2}{|c|}{ Age $\geqslant 70$ years } \\
\hline & $\begin{array}{l}\text { No of subjects ever } \\
\text { smoked/ never smoked }\end{array}$ & Risk ratio $(95 \% \mathrm{Cl})$ & $\begin{array}{l}\text { No of subjects ever } \\
\text { smoked/ never smoked }\end{array}$ & Risk ratio $(95 \% \mathrm{CI})$ \\
\hline \multicolumn{5}{|l|}{ Cases } \\
\hline \multicolumn{5}{|l|}{ Lung cancer: } \\
\hline Men & $789 / 128$ & $4.99(4.00 \text { to } 6.22)^{*}$ & $887 / 107$ & $4.90(3.93 \text { to } 6.10)^{*}$ \\
\hline Women & $72 / 242$ & $3.06(2.30 \text { to } 4.07)^{*}$ & $303 / 367$ & $4.10(3.43 \text { to } 4.91)^{\star}$ \\
\hline \multicolumn{5}{|c|}{ Any malignant neoplastic: } \\
\hline Men & $2228 / 889$ & $2.22(1.94 \text { to } 2.55)^{*}$ & $2120 / 693$ & $1.84(1.63 \text { to } 2.08)^{\star}$ \\
\hline Women & $193 / 1386$ & $1.60(1.33 \text { to } 1.93)^{*}$ & $634 / 1580$ & $2.00(1.76 \text { to } 2.28)^{\star}$ \\
\hline \multicolumn{5}{|l|}{ Respiratory: } \\
\hline Men & $532 / 152$ & $2.60(2.10 \text { to } 3.21)^{*}$ & $1763 / 668$ & $1.82(1.60 \text { to } 2.07)^{\star}$ \\
\hline Women & $47 / 145$ & $3.13(2.21 \text { to } 4.44)^{*}$ & $640 / 1544$ & $2.54(2.19 \text { to } 2.94)^{\star}$ \\
\hline \multicolumn{5}{|l|}{ Vascular: } \\
\hline Men & $872 / 404$ & $1.68(1.43 \text { to } 1.97)^{*}$ & $1508 / 913$ & 1.06 (0.94 to 1.19$)$ \\
\hline Women & $86 / 521$ & $1.55(1.20 \text { to } 1.99)^{*}$ & $586 / 2456$ & $1.29(1.13 \text { to } 1.48)^{\star}$ \\
\hline \multicolumn{5}{|l|}{ Other cause: } \\
\hline Men & $692 / 439$ & $1.27(1.07 \text { to } 1.51)^{*}$ & $778 / 538$ & 0.93 (0.80 to 1.07$)$ \\
\hline Women & $64 / 523$ & $1.16(0.87$ to 1.55$)$ & $332 / 1403$ & $1.18(1.01 \text { to } 1.38)^{*}$ \\
\hline \multicolumn{5}{|l|}{ All deaths: } \\
\hline Men & $4343 / 1892$ & $1.92(1.70 \text { to } 2.16)^{*}$ & $6185 / 2818$ & $1.41(1.28 \text { to } 1.55)^{\star}$ \\
\hline Women & $394 / 2583$ & $1.62(1.40 \text { to } 1.88)^{*}$ & $2196 / 7008$ & $1.68(1.52 \text { to } 1.86)^{\star}$ \\
\hline \multicolumn{5}{|l|}{ Live controls } \\
\hline Men & $841 / 639$ & 1.00 & $1502 / 923$ & 1.00 \\
\hline Women & $457 / 4473$ & 1.00 & $692 / 3491$ & 1.00 \\
\hline
\end{tabular}

*Statistically significant. †Adjusted for 5 year age groups and education.

Table 2 shows the main results for men and for women in middle age (35-69 years) and in old age $(\geqslant 70)$. For deaths from all causes, the risk ratio (smokers versus non-smokers standardised for age and education) was significantly elevated in middle aged men (1.92), elderly men (1.41), middle aged women (1.62), and elderly women (1.68), each $\mathrm{P}<0.0001$. When the causes of death were classified into four broad categories, we found significantly elevated risk ratios for malignant neoplasms and for respiratory disease in all four groups (middle aged men, elderly men, middle aged women, and elderly women). For vascular disease, the risk ratio was non-significant only in elderly men. For lung cancer, high risk ratios were found in all four

Table 3 Numbers of subjects who ever smoked or never smoked and adjusted risk ratios $†$ for smoking and mortality from selected causes among middle aged men and women in Hong Kong, 1998

\begin{tabular}{|c|c|c|c|c|}
\hline \multirow[b]{2}{*}{ Cause of death } & \multicolumn{2}{|c|}{ Men aged 35-69 years } & \multicolumn{2}{|c|}{ Women aged 35-69 years } \\
\hline & $\begin{array}{l}\text { No of subjects ever } \\
\text { smoked/ never } \\
\text { smoked }\end{array}$ & Risk ratio $(95 \% \mathrm{Cl})$ & $\begin{array}{l}\text { No of subjects ever } \\
\text { smoked/ never } \\
\text { smoked }\end{array}$ & Risk ratio $(95 \% \mathrm{Cl})$ \\
\hline \multicolumn{5}{|l|}{ Cases } \\
\hline \multicolumn{5}{|l|}{ Malignant neoplastic: } \\
\hline Lung cancer & $789 / 128$ & $4.99(4.00 \text { to } 6.22)^{*}$ & $72 / 242$ & $3.06(2.30 \text { to } 4.07)^{\star}$ \\
\hline Oesophageal cancer & $145 / 15$ & $7.89(4.49 \text { to } 13.88)^{\star}$ & $3 / 19$ & $1.60(0.47$ to 5.49$)$ \\
\hline Stomach cancer & $132 / 64$ & $1.72(1.24 \text { to } 2.38)^{\star}$ & $5 / 77$ & 0.69 (0.28 to 1.73$)$ \\
\hline Liver cancer & $392 / 215$ & $1.56(1.26 \text { to } 1.92)^{\star}$ & $17 / 126$ & 1.41 (0.84 to 2.38$)$ \\
\hline Five minor sitesł & $303 / 145$ & $1.94(1.52 \text { to } 2.48)^{*}$ & $14 / 105$ & 1.48 (0.83 to 2.63$)$ \\
\hline Other malignancy§ & $467 / 322$ & $1.25(1.04 \text { to } 1.51)^{\star}$ & $82 / 817$ & 1.14 (0.88 to 1.48$)$ \\
\hline Colorectal cancer & $142 / 139$ & 0.84 (0.64 to 1.09 ) & 18/186 & 1.03 (0.62 to 1.70$)$ \\
\hline \multicolumn{5}{|l|}{ Respiratory: } \\
\hline COPDף & $217 / 40$ & $3.68(2.58 \text { to } 5.26)^{\star}$ & $27 / 18$ & $13.27(7.19 \text { to } 24.49)^{\star}$ \\
\hline Respiratory tuberculosis & $36 / 11$ & $2.54(1.24 \text { to } 5.22)^{*}$ & $1 / 8$ & $1.49(0.18$ to 12.57$)$ \\
\hline Other respiratory & 279/101 & $2.15(1.66 \text { to } 2.79)^{\star}$ & 19/119 & 1.54 (0.93 to 2.53 ) \\
\hline \multicolumn{5}{|l|}{ Vascular: } \\
\hline Stroke & $315 / 140$ & $1.75(1.39 \text { to } 2.20)^{\star}$ & $31 / 235$ & 1.28 (0.87 to 1.89$)$ \\
\hline Ischaemic heart disease & $339 / 170$ & $1.58(1.27 \text { to } 1.97)^{\star}$ & $31 / 138$ & $1.96(1.30 \text { to } 2.96)^{\star}$ \\
\hline Other vascular & $218 / 94$ & $1.78(1.36 \text { to } 2.33)^{\star}$ & $24 / 148$ & $1.52(0.97$ to 2.40$)$ \\
\hline \multicolumn{5}{|l|}{ Other causes: } \\
\hline Other medical & $465 / 292$ & $1.29(1.07 \text { to } 1.55)^{\star}$ & $43 / 375$ & $1.04(0.75$ to 1.46$)$ \\
\hline Injury and poisoning & $227 / 147$ & 1.23 (0.93 to 1.63$)$ & $21 / 148$ & 1.49 (0.90 to 2.47$)$ \\
\hline \multicolumn{5}{|l|}{ Controls } \\
\hline & $841 / 639$ & 1.00 & $457 / 4473$ & 1.00 \\
\hline
\end{tabular}

*Statistically significant. †Adjusted for 5 year age groups and education. $\ddagger$ Cancer of the mouth, pharynx, larynx, pancreas, or bladder. §lncludes colorectal cancer. १Chronic obstructive pulmonary disease (or pulmonary heart disease). 
Table 4 Numbers of subjects who ever smoked or never smoked and adjusted risk ratios $\dagger$ for smoking and mortality from selected causes among elderly men and women in Hong Kong, 1998

\begin{tabular}{|c|c|c|c|c|}
\hline \multirow[t]{2}{*}{ Cause of death } & \multicolumn{2}{|c|}{ Men aged $\geqslant 70$ years } & \multicolumn{2}{|c|}{ Women aged $\geqslant 70$ years } \\
\hline & $\begin{array}{c}\text { No of subjects ever } \\
\text { smoked/ never } \\
\text { smoked }\end{array}$ & Risk ratio $(95 \% \mathrm{CI})$ & $\begin{array}{l}\text { No of subjects ever } \\
\text { smoked/ never } \\
\text { smoked }\end{array}$ & Risk ratio $(95 \% \mathrm{CI})$ \\
\hline \multicolumn{5}{|l|}{ Cases } \\
\hline \multicolumn{5}{|l|}{ Malignant neoplastic: } \\
\hline Lung cancer & $887 / 107$ & $4.90(3.93 \text { to } 6.10)^{\star}$ & $303 / 367$ & $4.10(3.43 \text { to } 4.91)^{*}$ \\
\hline Oesophageal cancer & $77 / 18$ & $2.17(1.28 \text { to } 3.66)^{*}$ & $12 / 23$ & $2.67(1.30 \text { to } 5.51)^{*}$ \\
\hline Stomach cancer & $129 / 65$ & 1.14 (0.83 to 1.56$)$ & $21 / 113$ & 0.95 (0.59 to 1.54$)$ \\
\hline Liver cancer & $204 / 104$ & 1.17 (0.91 to 1.52) & $35 / 120$ & 1.35 (0.91 to 2.01$)$ \\
\hline Five minor sitesł & $223 / 83$ & $1.68(1.28 \text { to } 2.20)^{*}$ & $36 / 121$ & $1.48(1.00 \text { to } 2.18)^{\star}$ \\
\hline Other malignancy§ & $600 / 316$ & $1.19(1.01 \text { to } 1.40)^{*}$ & $227 / 836$ & $1.36(1.14 \text { to } 1.61)^{*}$ \\
\hline Colorectal cancer & $234 / 121$ & 1.16 (0.91 to 1.48$)$ & $64 / 295$ & $1.07(0.80$ to 1.44$)$ \\
\hline \multicolumn{5}{|l|}{ Respiratory: } \\
\hline COPDI & $742 / 122$ & $3.81(3.08 \text { to } 4.71)^{*}$ & $272 / 177$ & $7.81(6.25 \text { to } 9.78)^{*}$ \\
\hline Respiratory tuberculosis & $63 / 25$ & $1.63(1.01 \text { to } 2.64)^{*}$ & $9 / 44$ & 1.03 (0.49 to 2.15$)$ \\
\hline Other respiratory & $958 / 521$ & $1.28(1.11 \text { to } 1.48)^{*}$ & $359 / 1323$ & $1.52(1.28 \text { to } 1.81)^{\star}$ \\
\hline \multicolumn{5}{|l|}{ Vascular: } \\
\hline Stroke & $556 / 339$ & 1.04 (0.89 to 1.23$)$ & $236 / 1070$ & 1.14 (0.96 to 1.37$)$ \\
\hline Ischaemic heart disease & $589 / 379$ & $1.02(0.87$ to 1.20$)$ & $217 / 835$ & $1.39(1.15 \text { to } 1.67)^{*}$ \\
\hline Other vascular & $363 / 195$ & $1.16(0.96$ to 1.42$)$ & $133 / 551$ & 1.25 (0.99 to 1.56$)$ \\
\hline \multicolumn{5}{|l|}{ Other causes: } \\
\hline Other medical & $684 / 466$ & $0.94(0.81$ to 1.10$)$ & $300 / 1286$ & 1.17 (0.99 to 1.38$)$ \\
\hline Injury and poisoning & $94 / 72$ & 0.82 (0.59 to 1.13$)$ & $32 / 117$ & 1.31 (0.86 to 1.98$)$ \\
\hline \multicolumn{5}{|l|}{ Controls } \\
\hline & $1502 / 923$ & 1.00 & $692 / 3491$ & 1.00 \\
\hline
\end{tabular}

*Statistically significant. †Adjusted for 5 year age groups and education. $\ddagger$ Cancer of the mouth, pharynx, larynx, pancreas, or bladder. §Includes colorectal cancer १Chronic obstructive pulmonary disease (or pulmonary heart disease).

groups, ranging from 3.06 in middle aged women to 4.99 in middle aged men.

Table 3 shows the risk ratios for several specific causes of death in middle aged men and women, and table 4 shows the corresponding results for elderly men and women. The most extreme risk ratio in the middle aged men was that for death from cancer of the oesophagus $(7.9,95 \%$ confidence interval 4.5 to 13.9$)$, but this result may have been inflated by chance, especially since the risk ratios for oesophageal cancer in the three other groups were substantially smaller. In middle aged men the risk ratio was 1.72 for stomach cancer and 1.56 for liver cancer (but only 0.84 for colorectal cancer) and was 1.94 for a pre-specified group of five types of cancer (mouth, pharynx, larynx, pancreas, and bladder) that have been found to be associated with smoking in other studies. ${ }^{2}$ For respiratory diseases, the risk ratios were 3.68 for chronic obstructive pulmonary disease and 2.54 for respiratory tuberculosis, while, for vascular diseases, the risk ratios were 1.75 for stroke and 1.58 for ischaemic heart disease: all of these risk ratios were highly significant $(\mathrm{P}<0.001)$ and involve diseases that might be caused or aggravated by smoking.

Table 5 shows the risk ratios for the four broad categories of disease and for the selected causes in middle aged men and women who smoked 1-14, 15-24, or $\geqslant 25$ cigarettes a day. Among the men, for each of the four broad categories of disease, there was a significantly positive dose-response relation (although it is fairly shallow for vascular mortality). For death from all causes, the risk ratios were 1.51, 2.01, and 3.31, indicating a highly significant trend of increasing mortality with increasing cigarette consumption.

The corresponding dose-response relations for elderly men and women are given in table 6 . Both in middle age and old age the death rates were significantly higher in smokers than in non-smokers. If this excess is largely or wholly causal then in Hong Kong in 1998 the numbers of deaths attributable to smoking were about 2534/7588 (33.4\%) in middle aged men, 2019/10 $107(20.0 \%)$ in elderly men, $169 / 3341(5.1 \%)$ in middle aged women, and 998/10 $313(9.7 \%)$ in elderly women. This indicates that the total number of deaths attributable to tobacco among people aged $\geqslant 35$ was 5720 (18.2\% of 31349$)$ and that tobacco was a cause of $25 \%(2703 / 10929)$ and $15 \%(3017 / 20420)$ of all deaths in middle aged and elderly people, respectively, in Hong Kong in 1998.

\section{Discussion}

Our study is the first to assess the hazards in a Chinese population that is at a fairly advanced stage of the epidemic of tobacco deaths among middle aged men, so it may well foreshadow what will happen among men throughout mainland China (and in other developing countries) over the next few decades. To help monitor the evolution of this epidemic, the methods of the present study could be used to assess tobacco related mortality in any other populations where death registration is organised centrally. Because interviewing was done in death registries, the coverage was high $(81 \%$ of all deaths at ages $\geqslant 35)$ and the time interval between death and interview was short, limiting recall error. As information was derived from the same proxy informant for both cases and controls, reporting bias should be minimal, at least for whether people ever smoked. In support of this, the risk ratios for colorectal cancer (which is largely unrelated to smoking in Western studies) were close to unity and the age-specific 
Table 5 Adjusted risk ratios $\dagger$ for mortality from selected causes or groups of causes by daily cigarette consumption among middle aged men and women in Hong Kong, 1998

Men aged 35-69 years

Women aged 35-69 years

\begin{tabular}{|c|c|c|c|c|c|c|c|c|}
\hline \multirow{3}{*}{ Cause of death } & \multirow{2}{*}{\multicolumn{3}{|c|}{ No of cigarettes smoked/day }} & \multirow{3}{*}{$\begin{array}{l}\text { Test for trend (P } \\
\text { value) }\end{array}$} & \multirow{2}{*}{\multicolumn{3}{|c|}{ No of cigarettes smoked/day }} & \multirow{3}{*}{$\begin{array}{l}\text { Test for trend ( } P \\
\text { value) }\end{array}$} \\
\hline & & & & & & & & \\
\hline & $1-14$ & $15-24$ & $\geqslant 25$ & & $1-14$ & $15-24$ & $\geqslant 25$ & \\
\hline \multicolumn{9}{|l|}{ Groups of causes } \\
\hline Malignant neoplastic & $1.64^{*}$ & $2.44^{*}$ & $4.10^{*}$ & $<0.001$ & $1.48^{*}$ & $1.68^{*}$ & $2.60^{*}$ & $<0.001$ \\
\hline Respiratory & $1.87^{\star}$ & $2.74^{\star}$ & $5.05^{\star}$ & $<0.001$ & $2.34^{*}$ & $3.92^{\star}$ & $10.54^{*}$ & $<0.001$ \\
\hline Vascular & $1.59^{*}$ & $1.57^{*}$ & $2.34^{*}$ & $<0.001$ & $1.43^{*}$ & $1.98^{*}$ & 2.03 & $<0.001$ \\
\hline Other cause & 1.06 & $1.31^{*}$ & $1.93^{*}$ & $<0.001$ & 1.14 & 1.21 & 1.11 & $<0.05$ \\
\hline $\begin{array}{l}\text { All deaths (No of cases, No of } \\
\text { controls) }\end{array}$ & $\begin{array}{c}1.51^{\star} \\
(1571,386)\end{array}$ & $\begin{array}{c}2.01^{*} \\
(1798,331)\end{array}$ & $\begin{array}{c}3.31^{*} \\
(768,86)\end{array}$ & $<0.001$ & $\begin{array}{c}1.47^{\star} \\
(243,309)\end{array}$ & $\begin{array}{c}1.84^{\star} \\
(106,108)\end{array}$ & $\begin{array}{c}2.63^{\star} \\
(33,25)\end{array}$ & $<0.001$ \\
\hline \multicolumn{9}{|l|}{ Selected causes } \\
\hline Lung cancer & $2.82^{\star}$ & $5.56^{*}$ & $12.72^{*}$ & $<0.001$ & $2.41^{*}$ & $4.19^{*}$ & $7.53^{*}$ & $<0.001$ \\
\hline Oesophageal cancer & $4.58^{\star}$ & $10.22^{*}$ & $13.78^{*}$ & $<0.001$ & 0.78 & $4.51^{*}$ & NS & 0.25 \\
\hline Stomach cancer & $1.69^{\star}$ & $1.77^{\star}$ & 1.79 & $<0.01$ & 0.59 & NS & NS & 0.12 \\
\hline Liver cancer & $1.39^{\star}$ & $1.67^{*}$ & $1.82^{\star}$ & $<0.001$ & 1.58 & 0.70 & 1.56 & 0.47 \\
\hline Cancer at five minor sites $\ddagger$ & $1.63^{*}$ & $2.19^{*}$ & $2.54^{*}$ & $<0.001$ & 0.93 & 2.20 & $6.91^{*}$ & $<0.01$ \\
\hline Other malignancy§ & 1.11 & 1.22 & $1.94^{*}$ & $<0.001$ & 1.22 & 0.91 & 0.88 & 0.69 \\
\hline Respiratory tuberculosis & 1.02 & $2.93^{*}$ & $6.62^{*}$ & $<0.001$ & 2.37 & NS & NS & 0.99 \\
\hline Other respiratory & $1.62^{\star}$ & $2.26^{*}$ & $3.46^{*}$ & $<0.001$ & 1.43 & 1.01 & $6.21^{*}$ & $<0.05$ \\
\hline Stroke & $1.58^{\star}$ & $1.79^{*}$ & $2.20^{*}$ & $<0.001$ & 1.16 & 1.75 & 1.48 & 0.10 \\
\hline Ischaemic heart disease & $1.55^{\star}$ & $1.32^{*}$ & $2.53^{*}$ & $<0.001$ & $1.85^{\star}$ & $2.45^{\star}$ & 2.38 & $<0.001$ \\
\hline Other vascular & $1.69^{*}$ & $1.72^{*}$ & $2.07^{\star}$ & $<0.001$ & 1.38 & 1.87 & 2.50 & $<0.05$ \\
\hline Other medical & 1.05 & $1.30^{*}$ & $2.17^{\star}$ & $<0.001$ & 1.04 & 1.02 & 0.90 & 0.95 \\
\hline Injury or poisoning & 1.18 & 1.30 & 1.22 & 0.16 & 1.36 & 1.89 & 2.31 & 0.07 \\
\hline
\end{tabular}

*Statistically significant risk ratios. †Adjusted for 5 year age groups and education. $¥$ Cancer of the mouth, pharynx, larynx, pancreas, or bladder. §lncludes colorectal cancer. $\Uparrow$ Chronic obstructive pulmonary disease (or pulmonary heart disease). NS=Not shown. Risk ratios unreliable because of insufficient number of smokers.

prevalence of smoking among controls approximately matches that in other surveys. ${ }^{6}$

If the excess mortality among smokers in table 2 (which depends only on whether subjects ever smoked) is accurately estimated and is largely or wholly causal then about half (48\%) of the deaths of male smokers in middle age are due to tobacco. If, furthermore, the doseresponse relationship in table 5 is roughly correct then among men who were light, moderate, and heavy smokers the respective proportions of deaths in middle age

Table 6 Adjusted risk ratios $\dagger$ for mortality from selected causes or groups of causes by daily cigarette consumption among elderly men and women in Hong Kong, 1998

\begin{tabular}{|c|c|c|c|c|c|c|c|c|}
\hline \multirow[b]{3}{*}{ Cause of death } & \multicolumn{4}{|c|}{ Men aged $\geqslant 70$ years } & \multicolumn{4}{|c|}{ Women aged $\geqslant 70$ years } \\
\hline & \multicolumn{3}{|c|}{ No of cigarettes smoked/day } & \multirow{2}{*}{$\begin{array}{l}\text { Test for trend } \\
\text { (P value) }\end{array}$} & \multicolumn{3}{|c|}{ No of cigarettes smoked/day } & \multirow{2}{*}{$\begin{array}{l}\text { Test for trend } \\
\text { (P value) }\end{array}$} \\
\hline & 1-14 & $15-24$ & $\geqslant 25$ & & 1-14 & $15-24$ & $\geqslant 25$ & \\
\hline \multicolumn{9}{|l|}{ Groups of causes } \\
\hline Malignant neoplastic & $1.44^{*}$ & $2.26^{*}$ & $2.50^{\star}$ & $<0.001$ & $1.82^{*}$ & $2.50^{*}$ & $2.47^{\star}$ & $<0.001$ \\
\hline Respiratory & $1.53^{*}$ & $1.95^{\star}$ & $2.90^{\star}$ & $<0.001$ & $2.07^{*}$ & $3.21^{\star}$ & $4.72^{\star}$ & $<0.001$ \\
\hline Vascular & 0.99 & 1.04 & $1.30^{*}$ & 0.10 & $1.26^{*}$ & 1.10 & 1.58 & $<0.01$ \\
\hline Other cause & 0.88 & 0.98 & 1.02 & 0.96 & 1.18 & 1.12 & 1.54 & $<0.05$ \\
\hline All deaths & $1.20^{*}$ & $1.57^{\star}$ & $1.92^{*}$ & $<0.001$ & $1.54^{*}$ & $1.87^{\star}$ & $2.20^{\star}$ & $<0.001$ \\
\hline \multicolumn{9}{|l|}{ Selected causes } \\
\hline Lung cancer & $3.37^{*}$ & $6.51^{*}$ & $7.29^{*}$ & $<0.001$ & $3.35^{*}$ & $6.20^{*}$ & $5.34^{*}$ & $<0.001$ \\
\hline Oesophageal cancer & 1.60 & $2.15^{\star}$ & $4.16^{\star}$ & $<0.001$ & $3.69^{*}$ & 0.87 & NS & 0.08 \\
\hline Stomach cancer & 1.05 & 1.15 & 1.42 & 0.25 & 1.004 & 0.96 & 0.93 & 0.94 \\
\hline Liver cancer & 1.03 & $1.46^{*}$ & 0.99 & 0.11 & $1.57^{\star}$ & 0.87 & 1.62 & 0.25 \\
\hline Cancer at five minor sites $\ddagger$ & 1.33 & $2.21^{*}$ & $1.69^{*}$ & $<0.001$ & 1.14 & $2.47^{\star}$ & 1.88 & $<0.01$ \\
\hline Other malignancy§ & 1.01 & $1.33^{*}$ & $1.65^{\star}$ & $<0.001$ & $1.35^{*}$ & 1.24 & $1.91^{*}$ & $<0.01$ \\
\hline Colorectal cancer & 1.05 & 1.15 & 1.68 & $<0.05$ & 1.13 & 0.94 & 1.32 & 0.63 \\
\hline COPDף & $2.85^{\star}$ & $4.36^{\star}$ & $6.44^{\star}$ & $<0.001$ & $5.97^{\star}$ & $10.00^{*}$ & $18.16^{\star}$ & $<0.001$ \\
\hline Respiratory tuberculosis & 1.31 & 1.42 & $3.26^{*}$ & $<0.01$ & 1.03 & NS & $5.22^{\star}$ & 0.87 \\
\hline Other respiratory & 1.17 & $1.30^{*}$ & $1.87^{\star}$ & $<0.001$ & $1.36^{*}$ & $1.82^{\star}$ & $2.13^{\star}$ & $<0.001$ \\
\hline Stroke & 0.99 & 1.05 & 1.33 & 0.17 & 1.21 & 0.79 & 1.47 & 0.44 \\
\hline Ischaemic heart disease & 0.92 & 0.98 & $1.40^{\star}$ & 0.23 & $1.34^{*}$ & 1.09 & 1.81 & $<0.05$ \\
\hline Other vascular & 1.16 & 1.14 & 1.08 & 0.38 & 1.07 & 1.47 & 1.71 & $<0.05$ \\
\hline Other medical & 0.89 & 1.03 & 1.02 & 0.83 & 1.18 & 1.06 & 1.58 & 0.07 \\
\hline Injury or poisoning & 0.86 & 0.71 & 1.07 & 0.39 & 1.19 & 1.60 & 1.05 & 0.22 \\
\hline
\end{tabular}

${ }^{*}$ Statistically significant risk ratios. †Adjusted for 5 year age groups and education. $\ddagger$ Cancer of the mouth, pharynx, larynx, pancreas, or bladder. §lncludes colorectal cancer. ๆChronic obstructive pulmonary disease (or pulmonary heart disease). NS=Not shown. Risk ratios unreliable because of insufficient number of smokers. 
that were attributable to tobacco were about $34 \%, 50 \%$, and $70 \%$ (that is, even among "light" smokers about a third of all premature deaths were due to tobacco).

In our study most of the risk ratios among middle aged men (smokers $v$ non-smokers) were substantially greater than those seen in 1988 in urban Chinese on the mainland, ${ }^{2}$ even though the tar yields of the (predominantly Western) cigarettes that have been sold in Hong Kong for many years are lower than those of the domestically produced brands that predominated on the mainland. For death from all causes, our risk ratio of 1.92 was greater than that of 1.29 in mainland China $^{2}$ and approaches the risk ratios seen in the United States and Britain. ${ }^{78}$ If this roughly twofold risk ratio persists when those now in middle age reach old age, it suggests that about half of the persistent cigarette smokers among Hong Kong Chinese will, like their counterparts in the West, eventually be killed by tobacco. Most of the excess mortality among smokers involved neoplastic, vascular, or respiratory diseases, which studies elsewhere have shown can be caused by smoking. One noteworthy finding is that for respiratory tuberculosis the risk ratio was $2.54 \quad(95 \%$ confidence interval 1.24 to 5.22 ), which is greater than the risk ratio of 1.42 found in mainland China. ${ }^{2} \mathrm{~A}$ dose-response relation between smoking and death from tuberculosis was observed in both studies.

In the United Sates the mean cigarette consumption rates per adult were 1,4 , and 10 a day in 1910 , 1930, and 1950; these rates were repeated in mainland Chinese men 40 years later (in 1952, 1972, and 1992, respectively). ${ }^{1}$ In Hong Kong, however, cigarette consumption in men had already reached 10 a day by the early $1970 \mathrm{~s},{ }^{45}$ which, although 20 years later than the United States, was 20 years ahead of mainland China. In 1955 about 21\% of all US male deaths in middle age and $5 \%$ of those at older ages were attributable to smoking. ${ }^{7}$ By 1975 , these attributable proportions had increased to $34 \%$ in middle age and $17 \%$ among older US men. ${ }^{7}$ Among Hong Kong men in 1998 about $33 \%$ of the deaths in middle age and $20 \%$ of those at older ages were attributable to smoking. These proportions are consistent with the hypothesis that the US pattern of overall mortality eventually attributable to smoking in men is being repeated in Hong Kong about two or three decades later.

Hong Kong has for the past few decades been the most urbanised and Westernised Chinese city. Although only a moderate hazard from smoking was found at an early phase of the growing epidemic of deaths from tobacco in mainland China, ${ }^{2}$ our study in Hong Kong shows a larger hazard at a later phase of the epidemic. The proportion of deaths attributed to smoking is more than twice as big in Hong Kong in 1998 as it was in mainland China 10 years earlier, ${ }^{2}$ which is consistent with the prediction of a large increase in mortality attributable to tobacco in China over the next few decades, ${ }^{1}$ unless there is widespread cessation by adults who already smoke. ${ }^{9} 10$

\section{What is already known on this topic}

China, with $20 \%$ of the world's population, smokes $30 \%$ of the world's cigarettes. Men smoke most, and the proportion of male deaths at ages 35-69 attributable to tobacco has been predicted to rise over the next few decades from 13\% (in 1988) to about $33 \%$

In Hong Kong cigarette consumption reached its peak 20 years earlier than in mainland China, so the epidemic of male deaths from tobacco should now be at a more advanced stage

\section{What this study adds}

In the general population of Hong Kong in 1998 tobacco caused about $33 \%$ of all male deaths at ages $35-69$ plus $5 \%$ of all female deaths, and hence $25 \%$ of all deaths at these ages

In the male smokers tobacco caused about half of all deaths at ages 35-69

The hazards now seen in Hong Kong foreshadow a substantial increase in tobacco deaths among middle aged men in mainland China over the next few decades if current smoking patterns persist

We thank our research staff and the Immigration Department of the Government of the Hong Kong Special Administrative Region. We particularly thank the relatives who provided information for this study.

Contributors: THL and SYH designed the study in consultation with $\mathrm{AJH}$ and RP and conducted it in cooperation with KHM, who supervised the encoding of the deaths. All collaborated in the statistical analysis and report writing. THL and SYH are guarantors for the study.

Funding: Hong Kong Health Services Research Committee (631012) and Hong Kong Council on Smoking and Health, plus direct support to CTSU by the Imperial Cancer Research Fund and the Medical Research Council.

Competing interests: None declared.

1 Peto R, Chen ZM, Boreham J. Tobacco-the growing epidemic. Nat Med 1999;5:15-7.

2 Liu BQ, Peto R, Chen ZM, Boreham J, Wu YP, Li JY, et al. Emerging tobacco hazards in China. 1: Retrospective proportional mortality study of one million deaths. BMJ 1998;317:1411-22.

3 Niu SR, Yang GH, Chen ZM, Wang JL, Wang GH, He XZ, et al. Emerging tobacco hazards in China. 2: Early mortality results from a prospective study. BMJ 1998;317:1423-4.

4 Millar S. Hong Kong human ecology programme. The biosocial survey in Hong Kong. Canberra: Central Printery, Australian National University, 1979.

5 Mackay JM, Barnes GT. Effects of strong government measures against tobacco in Hong Kong. BMJ 1986;292:1435-7.

6 Ho SY. Mortality attributable to smoking in Hong Kong [PhD thesis]. Hong Kong: University of Hong Kong, 1999.

7 Peto R, Lopez AD, Boreham J, Thun M, Heath C Jr. Mortality from smoking in developed countries 1950-2000. Oxford: Oxford University Press, 1994.

8 Doll R, Peto R, Wheatley K, Gray R, Sutherland I. Mortality in relation to smoking: 40 years' observation on male British doctors. BMJ 1994;309:901-11.

9 Peto R, Darby S, Deo H, Silcocks P, Whitley E, Doll R. Smoking, smoking cessation and lung cancer in the UK since 1950. BMJ 2000;321:323-9.

10 Peto R, Lopez AD. Future worldwide health effects of current smoking patterns. In: Koop CE, Pearson CE, Schwarz MR, eds. Critical issues in global health. San Francisco: Jossey-Bass, 2001:154-61.

(Accepted 5 July 2001) 